\title{
10 \\ THE WORK-FAMILY INTERFACE IN INDONESIA
}

\author{
Artiawati
}

\section{Introduction}

The headline in Kompas, the most popular daily newspaper in Indonesia, with the picture of Karen Agustiawan, the President Director of PT. Pertamina, the prominent gasoline and oil company owned by the government of Indonesia, attracted my attention and inspired me to start writing this chapter. Karen looked so sad reaching her hands out to her employees, who also looked very sad wanting to give her a farewell handshake. Under the picture there was a note saying:

"Karen mengundurkan diri per 1 Oktober 2014 dengan alasan ingin mengurusi keluarga dan meniti karier sebagai pengajar"

(Karen voluntarily quit as of 1 October 2014 due to her desire to care for family and to start a career as a lecturer).

Karen, 55 years old and a mother of three children, is a very famous woman in Indonesia. She was the first woman President Director of PT. Pertamina. Since she started her job as a director in the year 2009, she impressed many people, not only in Indonesia, but beyond, especially in leading giant gasoline and oil business corporations. Karen led PT. Pertamina to outstanding performance in many aspects.

Karen successfully acquired some famous oil companies in the world and brought PT. Pertamina into the group of the 500 richest companies in the world. PT. Pertamina is in the rank of 123, beating PepsiCo in the rank of 137, Unilever in the rank of 140, and Google in the rank of 162 (Wicaksono, 2014, reporting for Liputan 6, a famous portal newspaper in Indonesia, on 30 September 2014, 11.37). 
Even though many rumors were heard about Karen's resignation from the position of the President Director of PT. Pertamina, the fact of quitting jobs by women in Indonesia due to family reasons had always been accepted and even respected. In Wicaksono's report it was said that the Minister of State Owned Enterprises (Badan Usaha Milik Negara/BUMN), Dahlan Iskan, could not refuse Karen's resignation because she had already asked for it for several times and was willing to focus on her family life.

Success in a career does not seem meaningful when it is not aligned with success in family. A woman who prioritizes her family life is highly respected in Indonesia. It seems that a single type of a woman well accepted by the society in Indonesia is the one who is "married, has a child (children), and stays at home." If you happen not to meet one or any of these criteria, people often bother you with questions like:"Why don't you get married?";"Why are you not pregnant yet?”; and "Why do you have to work? What are you looking for?" Being a working woman seems to be not fully appreciated, especially when it is not accompanied by success in family life.

My curiosity to study the work-family interface actually started to emerge in 1993 when I first got a full-time job as an academic employee in the University of Surabaya, where I still work. To become permanent staff, I had to pass a oneyear probation period, in which I could not take a leave, even for a day. At that time, I had just given birth to my first daughter; therefore, my husband and I decided to move to a new house which was closer to my workplace. In short, my husband took a leave, and my mother-in-law came from Bandung, a city in West Java $750 \mathrm{~km}$ away from my place, and helped us with arranging the house. One day when I had just arrived to the office, my superior called me. I rushed in to her office and found myself in front of the Dean (female) and the Vice Dean (male). I was feeling uncomfortable seeing their firm expressions, while wondering what mistakes I had made. The Dean said:

"I heard you're moving your house ... and your husband and your mother-in-law are arranging that matter. I disagree with your attitude; it is very bad for a woman to do that."

TheVice Dean, who had a main duty as the Human Resource Manager then said:

"Now you go home and take your responsibility to care for your family."

(I said I was still on probation), but then he said: "Don't worry ... I allow you to go home and I guarantee that it will not be a problem for your employment."

While going home, I kept wondering why the dedication of a woman to her work seemed to be not respected, whereas dedication to her family was expected. Just before writing this part, I checked my son's bag (he's nine years old, a fourth grader in the primary school). He had a homework assignment for the subject of Bahasa Indonesia (Indonesian Language) about the rights and responsibilities of a 
mother and a father. It is written in the handbook that the rights of mothers and fathers are the same, and those are: being loved and being respected by the children. However, regarding the responsibilities, there were different statements that came in different numbers. The responsibility of fathers was only one, that was "to work," while the responsibilities of mothers were three: "take care of family, love children, and look after children."

Traditional gender-role ideology and patriarchal culture have been deeprooted in Indonesian society and are being taught to younger generations through the formal education system. Traditional gender-role ideology and patriarchal culture play a vital role in understanding WFC issues in Indonesia. Furthermore, as a collectivist culture, understanding the individual life of an Indonesian cannot be separated from an understanding of the societal belief systems influencing the belief system of that individual. I am often annoyed when men say: "A woman works just to avoid responsibility of doing domestic chores." In addition, I often hear a husband warn his working wife saying: "You may work, but don't forget about your responsibility to take care of the family." Juggling the demands of work and family often results in WFC.

This chapter describes the unique dynamics of the work-family interface occurring in Indonesia. The socioeconomic and cultural context of Indonesia and the summary of research on work and family issues in the country are provided in the beginning. The results of the focus group discussion with 10 Indonesian women workers are presented later, and finally, conclusions about the unique dynamics of work-family interface are discussed.

\section{Socioeconomic and Cultural Context of Indonesia}

Indonesia is a country in Southeast Asia, located between the Indian and Pacific Oceans. Having the total area of 1,904,569 $\mathrm{km}^{2}$, Indonesia is now the sixteenth largest country in the world. Furthermore, there are 17,508 islands in Indonesia, out of which only 6,000 islands are utilized. This makes Indonesia the only archipelago country in the world. Indonesia is divided into 33 provinces with two special regions and one special capital city area.

In 2003 Indonesia's population was 220 million, comprising 51\% female and $49 \%$ male. The latest population census in the year 2010 identified the number of population growth as 237,641,326 and the composition of female and male as $49.8 \%$ and $50.2 \%$, respectively. Even though the number of female citizens decreased, the composition of male and female citizens stayed relatively equal. Indonesia is fourth among the most populous countries in the world. In terms of age distribution, the majority of the population is 15-64 years old (66\%), and the remaining population is $10-14$ years old $(28.1 \%)$ or above 65 years old $(6 \%)$ (Kementerian Pemberdayaan Perempuan dan Perlindungan Anak, 2012a).

The majority of people in Indonesia (60\%) live on Java Island, which is relatively small $\left(138,794 \mathrm{~km}^{2}\right)$ compared to some other bigger islands such as Kalimantan 
$\left(539,460 \mathrm{~km}^{2}\right)$, Sumatra $\left(443,066 \mathrm{~km}^{2}\right)$, and Papua $\left(421,982 \mathrm{~km}^{2}\right)$. Indonesians with the Javanese ethnic background are around 41\% (around 100 million) of the total population. The influence of the Javanese culture, which is represented by beliefs of patriarchy and traditional gender-role ideology can be seen in many aspects of life of the Indonesian people. Not only Javanese, but most ethnicities in Indonesia, have adopted the same beliefs in different magnitudes. However, there is an ethnic group in Indonesia that is well known for adopting a matriarchy- the Minangkabau of West Sumatra. However, matriarchy in the Minangkabau ethnic group mainly encompasses two matters: the marriage process and inheritance issues. In most ethnic groups in Indonesia, the groom and his family propose to the bride. Conversely, in the Minangkabau ethnic group, the bride and her family should propose to the groom. Furthermore, in most ethnic groups in Indonesia men get a larger inheritance than women, while in Minangkabau women get the bigger portion.

Although Indonesia has more than 1,000 ethnic groups and more than 700 local languages, it has one national language, which is called Bahasa Indonesia (Indonesian language). Bahasa Indonesia was declared an official language of Indonesia on the 28 October 1928 in Sumpah Pemuda (Youth Pledge), at the Indonesian nationalist youth congress. Since then, every 28th of October the Indonesian people celebrate Youth Pledge Day to remember that we have one nation, one language, and one motherland-Indonesia. Most Indonesians speak Bahasa Indonesia more fluently than other local or foreign languages.

The Indonesian basic law and philosophy require all Indonesians to believe in God. Six religions are practiced in Indonesia: Islam, Catholicism, Protestant Christianity, Buddhism, Hinduism, and Confucianism. Most citizens of Indonesia are Muslims, despite a significant change in the last two decades. In the 1980s the number of Muslims in Indonesia was above 90\%, which decreased to $88.2 \%$ in the year 2000, and $85.1 \%$ in the year 2010. Religious life matters are arranged by the Ministry of Religion. However, as Islam in Indonesia has various streams, Majelis Ulama Indonesia (MUI/Indonesia Ulema Council), which comprises the representatives of various Muslim groups in Indonesia, plays a role in advising the Muslim community on existing issues by producing fatwa (legal opinion of qualified jurist pertaining to Islamic law) to avoid conflict among the streams.

Indonesia is still considered a developing country. Data from the Indonesian Statistic Body shows that GNP per capita in the year 2000 was Rp. 6,325,722, which increased in the year 2010 to Rp. 29,762,690, and in the year 2013 to Rp. 35,378,758. In the period between 2000 and 2010 the currency exchange rate was relatively stable ( 1 USD $=9,000$ rupiahs); however, in the year 2013 the currency rate changed to 1 USD $=12,000$ rupiahs, and remains relatively stable up to now.

The economic growth rate in Indonesia was increasing every year in the last decade. From 4.8\% in the year 2000 to $6.1 \%$ in the year 2010. In the year 2010 economic growth occurred in all sectors; the highest growth was in the 
communication and transportation sectors (13.5\%) and the lowest in the agricultural sector $(2.9 \%)$. The economic growth rate stayed relatively stable at around 6\% until 2012 (the pick number was 6.33\%); however, for the last two years it has been decreasing (as low as $5.21 \%$ in the year 2014).

As an agricultural country, employment in Indonesia is predominantly provided by the agricultural sector. However, in the years 2000-2010 there was a significant decrease, from $45.3 \%$ to $38.1 \%$. A slight decrease also occurred in the manufacturing sector, from $13.0 \%$ to $12.8 \%$. Conversely, an increase in employment numbers occurred in other areas, such as mining and quarrying $(0.5 \%-1.2 \%)$; construction (3.9\%-5.2\%); electricity, gasoline, and water $(0.1 \%-0.2 \%)$; communication and transportation $(5.1 \%-5.2 \%)$; finance, insurance, real estate, and business services (1.0-1.6\%); and personal, social, and community services (10.7\%-14.7\%).

Data from ILO Indonesia (2013) shows that most of the workforce in Indonesia was from three islands-Java, Bali, and Sumatera (in the middle to the west part of Indonesia) - accounting for $81.2 \%$ in the year 2012. Employment is still not well distributed, as the eastern part is still poor. However, the unemployment rate has tended to decrease over the last decade, from $9.06 \%$ in the year 2002 to $6.4 \%$ in the year 2012 .

The majority of the workforce in Indonesia still works in the informal sectors. Workforce in the informal sector from the year 2001 to 2009 was relatively stable, accounting for $61 \%-66 \%$. However, this number decreased for three years after, to $59 \%$ in the year $2010,54.7 \%$ in the year 2011, and $53.6 \%$ in the year 2012. A significant decrease in numbers occurred in the female workforce. In the year 2001 the share of women who worked in the informal sector was $67 \%$ and of men $57 \%$, while in the year 2012 it changed to $57 \%$ for women and to $51.2 \%$ for men.

Participation in the labor force in the year 2003 was $43.5 \%$ for women and $70 \%$ for men. This increased in the year 2010 and became $51.76 \%$ for women and $83.76 \%$ for men. Nevertheless, there are still not many women in managerial positions. The only woman governor existed in the year 2007. In the year 2011 there were only 16 female mayors out of a total of 497 mayors in Indonesia. Even though the number of women in managerial positions is growing, as in 2003 it was only around $1.2 \%$, the number of woman managers is still low, around $3 \%$ in the year 2012. A significant move in this direction was made by the seventh president of Indonesia, Joko Widodo, who was inaugurated in October 2014. Eight female ministers now assist him. Previously, in the period of 2009-2014, there were only four female ministers out of a total of 34 ministers in Indonesia (Kementerian Pemberdayaan Perempuan dan Perlindungan Anak, 2012b).

The Republic of Indonesia has been independent since the year 1945. Throughout the era of independence, the most tragic situation happened in the year of 1998, in which the Soeharto (the second president) regime fell after 32 years of Indonesia under his command. Accompanied by the worst monetary crisis, in that period Indonesia was in the hardest political and economic situation. Nevertheless, since then the more democratic era of Indonesia began. 
All Indonesian laws refer to the 1945 Constitution Basic Law and State Philosophy Pancasila (5 Basics), which are: (1) believe in the One Supreme God, (2) fair and civilized humanity, (3) unity of Indonesia, (4) deliberative democracy, and (5) social justice. These laws and philosophies guarantee equal rights to Indonesian citizens in the fields of education, law, health, political participation, and employment. Since the year 1983, Indonesia has had the Ministry of Women role arrangement, which, in the year 1999, after the Soeharto regime era ended, changed into the Ministry of Women Empowerment. As of 2009 the name has been modified to the Ministry of Women Empowerment and Children Protection. Nonetheless, inequality is still present in many sectors. Particularly in employment, women are still underpaid. Men can be paid as much as three times more than women.

The Indonesian law on workforce no. 13/2003 states that working more than 48 hours/week is excessive. However, data from the ILO (2012) found that in the year 2012, 55.96\% of the Indonesian workforce worked for more than 40 hours/ week (29.4\% worked for 40-48 hours/week, 15.09\% worked for 49-59 hours/ week, and $11.44 \%$ worked for more than 60 hours/week).

Economic reasons are a predominating factor for women to work in Indonesia. As a developing country, poverty is still experienced by $11.37 \%$ of the population, which makes it understandable that meeting their financial needs is challenging for many families. "Kemiskinan berwajah perempuan" (Poverty is represented by a woman's face). This statement is known in Indonesia to mean that when there is poverty, there is a woman making sacrifices, for example, going abroad as a migrant laborer.

As a country with highly traditional gender-role ideology and patriarchal culture, women in Indonesia are actually expected to stay at home, doing domestic chores and taking care of children. Having permission and support from their husbands is not that easy for many Indonesian women. When support is given, it is mostly because there is no other choice for the family to survive. The religious factor plays an important role in understanding the beliefs of Indonesian people in terms of banning women from work. As a Muslim majority country, people in Indonesia are very influenced by Islamic values, which support traditional genderrole attitudes. Indonesia is also a collectivistic culture, where family is a priority adopted by male and female workers (Artiawati, 2012).

The size of a family tends to be bigger after the fall of the Soeharto regime. In his period of presidency the family planning program was tightly controlled, as each family was suggested to have no more than two children. Nowadays, fewer people participate in the family planning program, although the mean size of a family in the year 2013 was still 3.9.

\section{Research on the Work-Family Interface in Indonesia}

It is not easy to find literature about work-family (W-F) life in the Indonesian context, especially any that was published internationally. However, research 
at the graduate and postgraduate levels pertaining to the W-F interface has been growing, and that helps us better understand the dynamics of WFC in Indonesia.

The first interesting research about working women I found a long time ago in the works of my lecturer, Dr. Parwati Soepangat, when I was an undergraduate student. Soepangat (1986), for her doctoral dissertation, conducted a study on 370 working women in Java. Results from this study showed that the level of education had no impact on self-awareness of women's empowerment due to the pervasiveness of sociocultural background. Furthermore, having a higher level of education did not influence the traditional gender-role ideology adopted by the women. Working women with different levels of formal educational background in this study adopted traditional gender-role beliefs.

Ten years later, Nainggolan, Candra, and Widyastuti (1996) conducted a study on four working women in Yogjakarata. The participants of this study had quit their jobs after delivering their first children. Causes for quitting were due to the WFC they experienced, a lack of support for child care, and their religious beliefs, which suggested that it was better for women to stay home and care for children.

Dewi, Artiawati, and Suvianita (2007) conducted a study of the dynamics of WFC among teachers. Using a qualitative approach and in-depth interviews, this study aimed at revealing the sources of WFC, the consequences of WFC, and the strategies to handle WFC experienced by the teachers. Participants of this study were six teachers in Surabaya (three women and three men).

Guru is an Indonesian term for teacher. Guru iku digugu omongane lan di tiru kelakoane, in Javanese language, means that the speech of a teacher is always copied, and the behavior of a teacher is always an example (model) for everybody, particularly for the student. In the Dutch colonial era, Indonesian people were proud to be called guru (teacher), as it was equal to priyayi (aristocrat). However, in this 21st century, most people think that the career of a teacher is not very promising, and salaries are low. Suroso (2002) reported that there still were primary school teachers receiving salaries of Rp. 94,000 (10 USD) per month, which was under the minimum regional wage in Jakarta, which was Rp. 320,000 (35 USD) at that time. Therefore, to cover the daily expenses of a family, most teachers, to find additional income, gave private classes to students. This situation led to work interference with family (WIF) conflict, as the time meant for family was spent for work after school time. Another source of WIF conflict included work overload, especially for teachers with structural positions. The teachers complained about occupying these positions as they did not receive more salary for undertaking the job. Family interference with work (FIW) conflict was also experienced by teachers and was caused by several factors, such as demands to care for children, especially those under five years old and teenagers, responsibilities to do domestic chores, and social activities for the family. A domestic helper was also a source of strain, as the attitude and character of the helper did not always match with teachers' expectations. 
The impact of the WFC experienced by the teachers was mainly expressed in losing concentration at work due to physical fatigue after working hard the day before. Coming late to school and withdrawal from work due to sickness were also impacts of WFC in the work domain. On the other hand, impacts on the family domain were complaints from the family members (spouse and children) because of the lack of time for family, physical problems (e.g., high blood pressure), being preoccupied by concerns for family and children, and feeling worried about the condition of the children.

Coping strategies applied to handle WFC were: getting support from parents and using domestic helpers. However, most respondents only used support from a domestic helper when their children were ages 2-11 years. Above 11 years old, children could be more independent and could even be a source of support themselves. They could help parents to sweep and clean the floor, and wash clothes using a washing machine. The financial issue also became a reason to stop using a domestic helper, as the expenses for raising elder kids grew, especially for their education.

Research about WFC in Indonesia has been conducted by researchers from various fields. Alteza and Hidayati (2009), researchers in the Economic and Social Sciences Department of State University of Yogjakarta, employed a case study approach utilizing in-depth interviews and participative observation. They conducted an interesting study on six working women in Yogjakarta, Indonesia. They investigated the sources and impact of WFC and coping strategies used to reduce WFC. Results from the study found that the sources of WFC were divided into areas of family and work. Sources coming from family included: a nonsupportive husband, difficulties managing children, nonavailability of a domestic helper, the role of a single parent, too many family demands, the responsibility to manage domestic chores, and demands for involvement in social activities.

Sources of WFC coming from the work context included: frequent schedules of meetings and supervision in the field, long distance from home to work (also problems of traffic jams), long work hours, work overload, nonconducive work environments, work overtime, and duty to work out of town.

The impacts of WFC were divided into three domains, encompassing impacts on the individual, family, and work domain. Impacts on individuals included: stress, lower concentration, over-sensitivity, gloominess, irritability, health disturbances (e.g., headache, tight muscles, vertigo), feeling sick and tired, limited interaction with spouse that led to misunderstandings, lack of intense kinship relationships, child becoming closer to the domestic helper, and speech problems of the child. Furthermore, impacts on the family domain included: learning difficulties for children, uncontrolled emotions, conflict among family members, frequent anger toward the domestic helper and children, arguing with extended family (parents) about the ways to teach children, children becoming spoiled, limited time for family gatherings, and insufficient time to care for children. In addition, impacts 
on the work domain were stress, low concentration on work, low performance, inhibition of finishing tasks, and not focusing at work.

Coping strategies to reduce WFC were divided into two types, which were emotion-based and problem-based.Among emotion-based strategies, it was found that working women more frequently engaged in religious activities, avoided conflict with extended family (parent), shared problems with friends, relaxed in a beauty salon, engaged in hobbies, and engaged in recreation activities out of town with family. On the other hand, problem-based coping strategies utilized included making rules in the family, employing a domestic helper and a driver, maintaining good communication with a spouse, trying to be firm with the children, asking for support from the workplace, using outside family services (food catering and laundry), work scheduling, daily scheduling and prioritizing, consulting with an expert counselor, doing karaoke with the family, asking for support from the extended family, asking for support from coworkers, and spoiling kids at holiday times.

Kesumaningsari and Simarmata (2014), researchers in the faculty of psychology and faculty of medicine at Udayana University, Bali, conducted research to examine the correlation between WFC and work engagement. Participants were 121 working women in the banking sector who were $22-55$ years old. Results from this study showed that there was a significant negative correlation between WFC and work engagement- the higher the WFC, the lower work engagement and vice versa. However, the level of WFC tended to be low.

The Balinese people have some different characteristics compared to the majority of Indonesians. Unlike the majority of Indonesians, who are Muslim, most Balinese are Hindu. Furthermore, Balinese women are commonly working in public; many of them are even breadwinners. The role of Balinese women is very complex. Upon getting married, a Balinese woman automatically becomes krama adat istri (women members of desa adat)custom village, in which Balinese people group). The intensity of custom ceremonies of Balinese Hindi is quite high, wherein married women have to fully participate as representatives of their families. All preparation and ceremonial activities become the responsibility of Balinese women, especially preparing sesaji (gift for God). Responsibility for domestic chores and as krama adat istri cannot be avoided by working mothers in Bali. Social sanctions will be applied if the working mothers do not meet those responsibilities. A Balinese woman will be seen as luh luu (misbehaved and rubbish women) by the society if she does not fulfill her domestic responsibilities, even if she has a high-level position in the workplace (Suatha, cited in Kesumaningsari \& Simarmata, in press). Similarly, if Balinese women are often not present at custom/ religious activities and ceremonies, they have to pay fines and will be alienated by the society (Saskara, Pudjihardjo, Maskie, \& Suman, cited in Kesumaningsari \& Simarmata, 2014).

High demands from the family domain, which create WFC, can be met by Balinese women using social support. The collectivist culture, which is present in 
the Balinese society, facilitates finding support for child care and doing domestic chores for Balinese working mothers. Husbands and extended family in Bali can be relatively easily asked to provide emotional and/or instrumental support. Received social support can lower the level of workload, and therefore reduce WFC. WFC, which tended to be low in this study, may also be influenced by the status of its participants, which was $90 \%$ staff. The work demands of staff are not as high as those of managers (Kesumaningsari \& Simarmata, 2014).

Desnawati (2008), the first student in the Master of Psychology Program, University of Surabaya, who did her master's thesis about W-F life found some interesting results. The study was aimed at improving the W-F balance of employees of the University of Surabaya. Desnawati first did an assessment of the conditions of employees, before creating intervention programs. She applied the qualitative as well as the quantitative approach to collect the data. She first conducted a focus group discussion with eight employees (six men and two women). She found that even though the participants expressed their ideas in different statements when asked about ideas of work and family, all could be summarized in one idea-that they worked for their families. They were aware that spending time for work would reduce time available for family; however, all work activities and results were for the continuity of the family life. Although all respondents felt that on the weekdays they spent more time on work activities than on family activities, they tried to have time for families during weekends.

It was interesting that when asked about WIF conflict, they could identify the source of WIF conflict, which was mostly long work hours. However, when they were asked about FIW conflict, at first they expressed ideas such as: "I don't feel so ... in principle, there is none ... family interferes with work . . . as a matter of fact, family supports work." "For me ... family never disturbs work."

But then a male respondent said that he felt preoccupied and could not concentrate when his child was sick. His wife was taking care of the child, but often contacted him while his child was sick. Female respondents got support from their extended families (the grandmothers) for taking care of children while the mothers worked. In general, the respondents said that they received full support from (extended) families, therefore they seldom experienced FIW conflict. The findings of the qualitative approach can complement and give clues to understanding the results from the quantitative approach.

Of 509 employees who were married with/without child(ren), 86 became participants (24 women and 62 men) for the quantitative study. Desnawati (2008) examined the roles of WFC and W-F guilt in predicting job satisfaction, family satisfaction, and life satisfaction. WFC was found to be a significant predictor of job satisfaction and family satisfaction. However, only family satisfaction, and not job satisfaction, was a predictor of life satisfaction. Furthermore, although WIF guilt was a significant predictor of job satisfaction and family satisfaction, FIW 
guilt predicted neither job satisfaction nor family satisfaction. Most respondents had low levels of WFC (only 2.3\% respondents had high WFC), because most respondents received social support, especially from their families, which could reduce WFC.

A study about WFC and social support was also done by Leofianti (2013). She conducted a study on 70 nurses to find correlation between social support and WFC. Social support in her study came from three sources: superior, coworker, and husband. Leofianti found that nurses in Yogjakarta, Indonesia, experienced WFC, both WIF and FIW. In her preliminary study, she found a nurse, namely Mawar (42 years old, work experience 17 years), who experienced WIF conflict because of the fixed shift schedule imposed by the management of the hospital. Mawar said: "I felt annoyed because if there was a family gathering, I could not make it because I had to stand by in the hospital. The schedule for shift work was arranged by the hospital management, I could not choose." On the other hand, FIW conflict in Leofianti's study occurred due to problems with child care. Siti (35 years old, 10 years of work experience) said: "I really wanted to rush home when my child was sick. I had no heart ... if I left my child only with 'mbah' nya (the kid's grandmother)."

Surprisingly, Leofianti (2013) found there was no correlation between social support and WFC. However, some interesting results showed that WFC experienced by the participants tended to be low, while social support received tended to be high. In addition, the location of the hospital where the participants worked was different from the preliminary study. The location for the preliminary study was in Yogjakarta city (urban), while the actual study was carried out in Bantul (a rural part of Yogjakarta). Demands from work were relatively low, as the hospital was in the rural area. Furthermore, the hospital in Bantul was more flexible in arranging work schedules. The hospital in Bantul had a system that enabled nurses to take leaves without jeopardizing the schedule. There were some nurses who only worked when the nurse in charge took a long leave, such as a maternity leave.

Collectivism was also strongly seen in Bantul society. The extended family could not only be asked for help for undertaking domestic chores, but also neighbors could provide support, particularly in child care. In addition, when we look into the belief system of Javanese (Yogjakarta is part of Java), it is known that the Javanese adopt the philosophy of nrimo ing pandum, which means "always accept every condition through feeling blessed." The study also found that there were different levels of WFC experienced by junior and senior nurses. Senior nurses had higher levels of WFC (particularly strain-based WIF conflict) than junior nurses. This could be caused by the different workloads of senior and junior nurses. Many senior nurses also occupied managerial positions. Furthermore, doctors preferred to be assisted by senior nurses, as they were more skillful and 
the nurses were reluctant to refuse their requests. Javanese people are also known to have personal characters such as sungkanan and/or ewuh pakewuh (hesitation to refuse/to frankly speak about feelings, also could be said as less assertive). Furthermore, senior nurses had to also teach junior nurses, and they all too often felt annoyed when working with unskilled coworkers. All this increased their workload and strain.

To more comprehensively examine the antecedents and outcomes of WFC, Artiawati (2009) conducted a study with the Project 3535 data from Indonesia using the model proposed by Aycan (2006), in which work and family support and work and family demands play a role as antecedents for WFC. On the other hand, negative work, family, and life outcomes are consequences of WFC. The study was done using 268 workers (150 women and 118 men) from education, health, manufacturing, and finance sectors. The results of this study were different from Aycan's study, in which the model fit the Turkish sample. For the Indonesian sample the model did not meet the criterion of goodness of fit. However, some interesting findings could be seen through the dynamics of the results. Work and family support were significantly associated with work and family demands; however, work and family demands were not significantly associated with WFC. Furthermore, WFC was significantly associated with negative work and family outcomes. Nevertheless, similar to Desnawati (2008), life outcomes were only associated with family outcomes.

Rajadyaksa, Huang, and Artiawati (2011) also used the data from Project 3535 to examine the model of antecedents and consequences of WFC in three countriesIndia, Taiwan, and Indonesia. Gender-role ideology (GRI) and work and family overload played a role as antecedents for WFC, while work and family guilt played a role as the consequence of WFC. Three different samples, 561 Indians, 281 Taiwanese, and 306 Indonesians, participated in this study. Results from this study showed that all the path coefficients in the model were in the hypothesized direction for the three countries, indicating that GRI predicted WFC in the same manner among the three Asian countries. More traditional GRI was associated with higher W-F demands, higher WFC, and higher W-F guilt.

Results did not vary for men and women within the three countries; however, some specific dynamics in each country could be identified. In Taiwan and Indonesia, higher work demands (overload) did not significantly increase W-F guilt, which could be explained by work and family demands (overload), both being perceived as part of the responsibility toward family. Nevertheless, unlike India and Taiwan, for Indonesia traditional GRI was not associated with higher W-F overload. The role of social support, which is relatively easy to get in a collectivist culture such as in Indonesia, needs to be considered to understand this result. Social support can significantly reduce W-F overload (Artiawati, 2009). Furthermore, as mentioned in Leofianti (2013), the acceptance attitude of Indonesians may have influence so that work overload is seen as something to be accepted and 
feel blessed with, also taking traditional gender orientation for granted. Research from Artiawati (2012) can explain the dynamics occurring among Indonesians more clearly.

Artiawati (2012) examined the model of antecedents and consequences of WFC on 360 journalists (100 women and 254 men, 6 missing) in six provinces located in Java and Bali. The following were considered as antecedents of WFC: GRI, work and family role overload, social support (from superior and spouse), and personality (Big Five). On the other hand, work and family guilt, and psychological well-being were consequences of WFC. Results from this study represent the uniqueness of Indonesian culture, which is strongly influenced by patriarchal beliefs and high collectivism.

Using path analysis, the model met the criterion of the goodness of fit, where GRI,W-F overload, social support, and personality were the antecedents of WFC, while W-F guilt and psychological well-being were the outcomes of WFC. Furthermore, this study showed traditional GRI was not significantly associated with role overload and WFC. In addition, support from the spouse and superior were high. Triandis, Bontempo, Villareal, Asai, and Lucca (1988) mention that the psychological level of allocentrism, as the dimension of collectivism, is positively correlated with social support; therefore, in the collectivist society like Indonesia, support is relatively easy to find. However, this study showed that while support from a spouse could effectively reduce family role overload, support from a superior could not reduce work role overload. Journalists in managerial positions tended to have higher work role overload and needed support more from coworkers (for coordination) and subordinates (for doing tasks related to reporting and editing processes). As coworkers could not well coordinate and subordinates did not meet deadlines, journalists in managerial positions tended to take over their tasks, which made them work overtime or take work home. This condition caused WIF conflict.

Agreeableness was the only trait that was significantly correlated with WIF conflict. The correlation was positive, which meant that higher agreeableness was associated with higher WIF conflict experienced by the respondents. Lack of assertiveness, difficulty to refuse, and difficulty to express disagreement are representing the agreeableness trait. Workers, especially the managers (editors), were less assertive in refusing work overload, therefore they were in the end taking too many responsibilities. In family domain, the only trait significantly associated with FIW conflict was neuroticism. The correlation was in the positive direction, which means the higher neuroticism, the higher the FIW conflict experienced. Family is the primary concern of Indonesian life.

The meaning and appreciation of traditional gender-role ideology by male and female workers in Indonesia may be different. However, both male and female workers experienced WFC. Even though in this study both genders experienced low WFC, WFC in men was slightly higher than it was among women. It was 
almost similar to the condition in India, wherein female workers had prepared themselves for juggling many tasks (due to the belief system about women's duties), while male workers were not prepared to deal with the complexity of W-F life (Desai, 2005).

Artiawati (2012) also conducted a qualitative study conducting three sessions of focus group discussions with six journalists (four women, two men) in Bandung (west Java), three journalists (two women, one man) in Yogjakarta (near central Java), three journalists (four women, one man) in Bali; and seven interview sessions with journalists (three women, four men) representing all six provinces. Of the male journalists involved in the FGD and interviews, only two felt that women should work. Both of them had working wives. Another three journalists said it was fine for women to work, but their wives were not working women. One male journalist firmly disagreed with women working. He said: "It is so sad for her children if she works." However, this journalist had a wife working as a nurse. The reason why his wife worked was because of the financial demands of family, which could not be fulfilled if he were the only one who worked in the family. From these results, it seems that women in Indonesia are expected to play a role in the domestic domain more than in the public domain.

Triandis et al. (1988) mention,

"Conformity may occur more frequently in collectivist cultures when the norms are clear, and sanctions are likely to be imposed for deviant behavior."

"Saya ini perempuan tradisional lo mbak ..." (I'm such a traditional woman ... sister.)

This sentence was often said by female respondents.

In a more detailed explanation, Helia, a woman editor with three children said:

"I never have a helper ... all domestic chores are done by myself (sounds very proud of herself), my hobby is also cooking ... I'm a traditional woman ... so ... even though I'm working ... children and housekeeping are handled by me ... children ... husband ... respect me ... although actually my husband feels pity ... he actually doesn't like (disagree) that I work ... but see ... you can see my house (her house looks neat, beautiful, and comfortable, with the touch of uniqueness of traditional Java design) ... many of my friends ... especially expatriates ... are pleased to stay in my house."

Conformity to traditional gender orientation, is a safe choice for women in Indonesia, and complying to norms as a traditional woman will help avoid social sanctions. It could be understood from the results of the study that showed that traditional gender-role ideology was positively correlated with psychological well-being. 


\section{Results of Focus Group Discussions}

Two sessions of focus group discussions (FGD) were conducted to find out the following: (1) how often participants experienced WIF and FIW, (2) sources of WIF and FIW, (3) outcomes of WIF and FIW, (4) coping strategies applied to reduce WFC. Participants of this study were 10 working women. Each session of focus group discussions had five participants and took around two hours to discuss the issues. All participants were married at the time of FGD, but varied in terms of other demographic characteristics. More detailed information about the participants can be found in Table 10.1 .

TABLE 10.1 Demographic characteristics of participants in focus group discussions.

Age (in years)
Under 30
30-40
Above 40
Education
Bachelor's Degree
Master's Degree
Doctoral Degree
Religion
Muslim
Catholic
Protestant Christian
Ethnicity
Javanese
Chinese Javanese
Occupation
Lecturer
Lecturer with Managerial Experience
Business and Development Manager
Work experience (in years)
Under 5
5-10


TABLE 10.1 (Continued)

\begin{tabular}{lc}
\hline Demographic Characteristics & Number of Participants \\
\hline Husband's occupation & \\
Staff & 2 \\
Manager & 4 \\
Entrepreneur & 4 \\
Length of marriage (in years) & \\
Under 5 & 2 \\
$5-10$ & 5 \\
Above 10 & 3 \\
\hline
\end{tabular}

All participants were very enthusiastic and actively participated in the process of discussion. The situation was very conducive to making all participants open to sharing their feelings and ideas. The laughter and expression of sadness happened interchangeably during the discussion session. At the end of the session, the participants were expressing feelings of relief. They felt relief to have shared many things that they had kept in themselves for so long. They were also happy to know that they were not alone in experiencing WFC.

Results from the focus group discussion revealed some interesting themes. Most importantly, all participants mentioned that they experienced WIF conflict more often than FIW conflict. It seems work life is more difficult to manage, and therefore, it is more challenging when considering the effort for balancing the work and family life. In the next part, antecedents and outcomes of WIF and FIW conflict, as well as coping strategies to balance work and family life, are discussed.

\section{Antecedents and Outcomes of WIF Conflict}

The source of WIF conflict came from work demands, which were identified as: ineffective management (meeting after work hours), lack of reliable administrative supports, indecisive leadership from superiors, and unskilled coworkers/subordinates. This all ended up in work overload due to taking too many responsibilities.

One of the participants, namely Tita (44 years old, manager), mentioned that she often brought her work home because otherwise she would come home very late if she did all the work at the office. She said laughing, but with sadness showed in her expression:

"I have one experience ... I did not know that my husband had been waiting for me till late at night in the bedroom, I thought he already slept. He started screaming when I entered the bedroom bringing lots of my paperwork. What? You still keep working? And he went to sleep with anger. I felt discomfort and guilt, but the deadline for submitting the work was the next day." 
The outcomes of WIF conflict are feeling guilt, sleep deprivation, and exhaustion.

\section{Antecedents and Outcomes of FIW Conflict}

The source of FIW conflict came from family demands, which included problems of caring for children and providing education for them, caring for the elderly, unequal distribution of handling domestic chores with a spouse, unavailable or incompetent domestic helpers, demands from extended family, and jealousy and conflict with a spouse. A young manager, Yani (30 years old), who looked desperate while talking, said:

"My husband always scowls if I have a telephone call from my male subordinate ... who is only calling to consult about urgent things . . . but my husband seems very jealous him ... My husband thinks that my subordinate just tries to find reasons to contact me at home. My coworkers and subordinates are not as capable as I would like, and as a result it makes more work for me. In addition, my boss is indecisive. And my home life is impacted by my husband's jealousy of the phone calls from my male subordinate."

The extended family can also become a source of strain. Nita (34 years old, staff) talked expressively and felt annoyed when sharing her experience. She said:

"I get stressed when facing my husband's family. They often come to my house and spend a long time at my house. Especially my sister-in-law, she doesn't care whether I'm busy or not. She insists on me accompanying her just for sightseeing and shopping."

Outcomes of FIW conflict were: low work motivation, difficulty concentrating on the job, withdrawal from work, distress, irritability, and guilty feelings. Panic and sadness were also often felt when having sick children at home.

\section{Strategies Used to Cope with W-F Conflict}

Coping strategies to reduce WFC can be divided into three domains: personal, family, and organizational. For the personal domain the strategy of coping was aimed at reducing distress and strain. All participants had a unique way to release their distress. They tried to find a "me time" by doing an activity alone, including going to the beauty salon and spa or a bookstore, driving a car and turning favorite music a bit loud, and religious activities such as praying and reading the holy book (the Qur'an). In the family domain, coping strategies applied included asking for support from the extended family, a neighbor, a coworker, and a domestic helper; 
using equipment at home to make the domestic chores easier (washing machine and microwave); subscribing to daily food catering services; and living in a house close to the office.

On the organizational level, child care is available, but people still hesitate to use it. As much as they can, they are not sending their children to child care. They prefer their children to be looked after by the extended family or relatives (including coworkers).Yanti again said:" Anak kok dititip-titip . . memangnya barang" (it is difficult to find an exact translation, but the meaning is about wondering and complaining about why people send their children to an external agent; it is like depositing stuff). On the organizational level, it is also relatively easy to ask permission for handling urgent domestic demands. Taking the child to the workplace when no one can look after him/her at home is a common and acceptable practice in many organizations in Indonesia. Even though child care and elder care facilities are now available, they are rarely utilized. Sending children to child care or a family member to elder care causes humiliation and resentment in Indonesia.

\section{Special Themes Found in the FGDs}

Extended family could be a source of support as well as a source of strain. The situation was similar with domestic helpers; they could be a source of support when they are skillful and cooperative, but when they are not skillful and not cooperative, this could be a source of strain to working women. Domestic helpers staying at home are commonly found in many families. Yanti (38 years old, manager) shared her experience in handling problems with her domestic helper.

"My servant is not skillful, so I have to teach her all the time. She is now pretty good about handling the domestic chores. . . However, another problem appeared when she had a boyfriend ... she often disappeared ... so I made a schedule for her when she could leave home for dating ... I asked her for cooperation to obey the schedule. Not only that, I also asked her to introduce her boyfriend so I could be sure with whom she went out. Her relatives also often come to visit her, to take her salary or ask permission to take her home for a couple of days. So I have to also get in contact with her family circle to handle them so that they don't bother us so often."

WFC experienced was also causing some participants to intend to quit their job and marriage, but it was difficult to do because of social and religious sanctions. Santi (33 years old, staff, with two children) mentioned that her decision to work was based on her bad experience when she was not financially independent due to not working. She said:

"I was feeling that I'm in the lowest point of my life when I asked money from my husband for daily needs of family ... and my husband said angrily ... 
where is the money I gave to you yesterday? You used it all? ... At that time I swore that I would work and keep working no matter what. Since I work, my husband started complaining and keeps complaining. He allows me to work, but he imposed on me to do all the domestic chores and care for my two kids. I feel a burden arguing every time with him ... and frankly I really, really don't like doing domestic chores. I want him to do some of the domestic chores ... at least we can share. I'm thinking of divorce but still confused ... what will people say if I get divorced?"

Even though Santi disliked doing domestic chores, other participants enjoyed doing domestic chores. Moreover, they sometimes experienced the feeling of being "lost" when they could not do some domestic chores. Doing domestic chores made women happy because they received appreciation from family, especially from their spouse. Tita again said:

"I get up early every morning and before sunrise I already go to the traditional market near my house preparing all stuff for cooking. My husband likes my cooking, and it makes me happy ... but when I'm sweeping outside my house, suddenly my daughter calls me loudly ... Mom, get in please ... I don't like people seeing you sweeping to think you are a housewife, my mom is a manager."

It seems there is a shifting perspective in how the younger generation see the value of working woman, especially from the female perspective. Being a working woman will increasingly be a preference for young women.

\section{Conclusion}

Women in Indonesia are faced with demands to carry more responsibilities in the domestic life due to traditional gender-role ideology adopted by the majority of the Indonesian society. There is no excuse for women who work in public sectors not to take responsibility in domestic life. Juggling demands from work and family causes work conflict for working women in Indonesia. Nevertheless, as a collectivist culture, it is relatively easy to find social support that can decrease the occurrence of WFC. Caring for children and doing domestic chores are highly respected parts of women's roles, as it's seen as dedication to the family. Conformity to the beliefs in traditional gender-role ideology is a safe choice for women in Indonesia to avoid social sanctions, and one which, in the end, can increase well-being. Work-family conflict is also experienced by male workers, as the wellbeing and life satisfaction of Indonesian people are predominantly influenced by the family domain (family satisfaction). This occurs due to the collectivist culture in Indonesia, in which belongingness to the group (in-groups), particularly a family, is very strong. Family is the first priority for Indonesian people. Further research is needed to explore more about the dynamics of work-family interface issues as Indonesia has many subcultures. 


\section{References}

Alteza, M., \& Hidayati, L. N. (2009). Work-family conflict pada wanita bekerja: Studi tentang penyebab, dampak dan strategi coping [Work-family conflict on working women: Study about source, impact and coping strategy]. Research report for Faculty of Economic and Social Sciences, Universitas Negeri Yogjakarta, Indonesia.

Artiawati. (2009). Anteseden dan konsekuensi konflik kerja-keluarga pada manajer dan pekerja di Indonesia [Antecedents and consequences of work-family conflict on managers and workers in Indonesia]. Simposium Kebudayaan Indonesia-Malaysia (Symposium of IndonesiaMalaysia Culture) IX, Bandung, Indonesia.

Artiawati. (2012). Konflik kerja-keluarga pada jurnalisi di Jawa dan Bali (Model konflik kerjakeluarga dengan ideologi peran gender, beban peran berlebih, dukungan sosial dan kepribadian sebagai anteseden; rasa bersalah dan kesejahteraan psikologis sebagai konsekuensi) [Work-family conflict among journalists in Java and Bali (the model of work-family conflict with gender role orientation, role overload, social supports and personality as antecedents; guilty feeling and psychological well-being as consequences)] (Doctoral dissertation). Doctoral Program in Psychology, Universitas Padjadjaran, Bandung, Indonesia.

Aycan, Z. (2006). Work-family conflict in Turkey: Societal change and policy implications. Paper presented at the International Conference of Applied Psychology, Athens, Greece.

Badan Pusat Statistik Indonesia (the Statistic Central Body of Indonesia), retrieved from http://www.bps.go.id/

Desai, T. P. (2005). India: At multiple crossroads of work-family conflict. Paper presented at the First International Conference: Community, Work and Family, Change and Transformation, Manchester, United Kingdom.

Desnawati, S. (2008). Upaya meningkatkan keseimbangan kehidupan kerja-keluarga di Universitas Surabaya [Effort on improving work-family life balance in University of Surabaya] (Postgraduate thesis). Master of Psychology Program, Universitas Surabaya, Indonesia.

Dewi, L. K., Artiawati, \& Suvianita, K. (2007). Dinamika konflik kerja-keluarga pada guru [The dynamic of work-family conflict on teacher]. Anima Indonesian Psychological Journal, 2(3), 263-275.

ILO Indonesia. (2012). Tren Ketenagakerjaan dan Sosial Indonesia 2011: Mempromosikan pertumbuhan lapangan kerja di tingkat provinsi, Kantor Perburuhan Internasional Jakarta [Labour and Social tends in Indonesia: Promoting job-rich growth in provinces]. International Labour Office, Jakarta, Indonesia.

ILO Indonesia. (2013). Tren Ketenagakerjaan dan Sosial Indonesia 2012: Upaya untuk menciptakan ekonomi yang adil dan berkelanjutan, Kantor Perburuhan Internasional Jakarta [Effort to build economic fairly and continuously]. International Labour Office,Jakarta, Indonesia.

Kementerian Pemberdayaan Perempuan dan Perlindungan Anak. (2012a). Pembangunan Manusia Berbasis Gender 2012. Jakarta: Kementerian Pemberdayaan Perempuan dan Perlindungan Anak (Ministry of women empowerment and children protection).

Kementerian Pemberdayaan Perempuan dan Perlindungan Anak. (2012b). Profil Perempuan Indonesia 2011 [Profile of Indonesian Women 2011]. Jakarta: Kementerian Pemberdayaan Perempuan dan Perlindungan Anak (Ministry of women empowerment and child protection).

Kesumaningsari, N.P.A., \& Simarmata, N. (2014). Konflik kerja keluarga dan work engagement karyawati Bali pada Bank di Bali [Work-family conflict and work engangement on Balinese women employees in Bali). Journal Psikologi Indoonesia, 1(3), 493-506, Program Studi Psikologi, Fakultas Psikologi Universitas Udayana. 
Leofianti, A. R. (2013). Hubungan antara dukungan sosial atasan, dukungan sosial rekan kerja dan dukungan sosial pasangan terhadap work-family conflict pada perawat rumak sakit swasta di Yogjakarta [Correlation between social support from superior, co-worker, spouse and work-family conflict on nurses in a private hospital in Yogjakarta]. (Udergraduate thesis). Faculty of Psychology, Universitas Gadjah Mada, Yogjakarta, Indonesia.

Nainggolan, C., Candra, P., \& Widyastuti, A. (1996). Studi kasus tentang faktor-fator yang mempengarungi keputusan untuk berhenti bekerja pada wanita setelah kelahiran anak pertama [The case study of factors influencing decision to quit job on women after first child's birth]. Jurnal Psikologi dan Masyarakat, 2, 75-109.

Rajadyaksa, U., Huang, T., \& Artiawati. (2011). Gender role ideology, work-family overload, conflict and guilt: Examining a path analysis model in three Asian countries. Paper presented in Regional Conference International Association of Cross-Cultural Psychology, Istanbul, Turkey.

Soepangat. (1986). Pengaruh lingkungan budaya terhadap keibuan dan emansipasi sebagai bentuk aktualisasi diri wanita: Studi kasus para ibu-ibu pekerja di beberapa kota di Jawa; Suatu Pendekatan melalui teori psikologi budaya. [The influence of cultural environment towards mothering and emancipation as a form of the women's self-actualization: A case study of working mothers at several places in Java: A cultural psychology approach] (Doctoral Dissertation). Universitas Padjadjaran, Bandung, Indonesia.

Suroso (2002). In memorium guru. Yogjakarta: Jendela.

Triandis, H. C., Bontempo, R.,Villareal, M. J., Asai, M., \& Lucca, N. (1988). Individualism and collectivism: Cross-cultural perspectives on self-ingroup relationships. Journal of Personality and Social Psyhology, 54(2), 323-338.

Wicaksono, P. E. (2014). Karen Agustiawan Mundur dari Dirut Pertamina pada 1 Oktober 2014) [Karen Agustiawan quits as the President Director of Pertamina on 1 October 2014], liputan6.com, Jakarta. 


\section{THE WORK-FAMILY INTERFACE IN \\ GLOBAL CONTEXT}

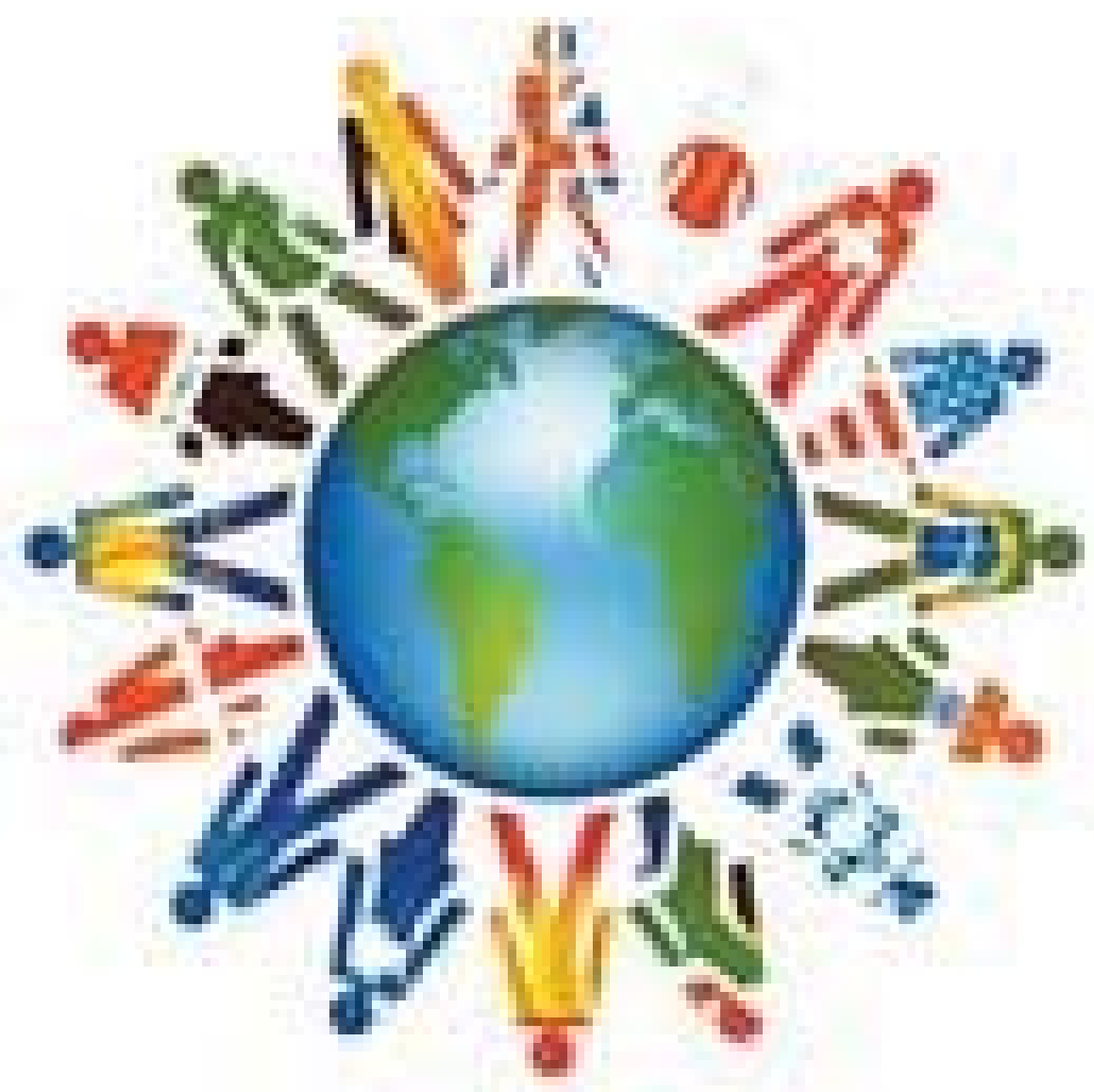

Editud hy Koren Kontt. Zuprep Aroan and Fono Aymon

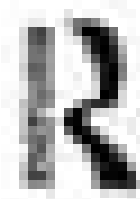




\section{Book Description}

Based on a sweeping, ten country study, The Work-Family Interface in Global Context comprises the most comprehensive and rigorous cross-cultural study of the work-family interface to date. Just as work-family conflict is associated with negative consequences for workers, organizations, and societies, so too can the work and family domains interact positively to enhance or enrich one another. Drawing on qualitative, quantitative, and policy-based data, chapters in this collection explore the influence of culture on the work-family interface in order to help researchers and managers understand the applicability of work-family models in a variety of contexts and further conceptualize work-family interactions through the development of a more universal knowledge.

\section{Members of the Project 3535 Team:}

Karen Korabik, University of Guelph, Canada.

Zeynep Aycan, Koç University, Turkey.

Roya Ayman, Illinois Institute of Technology, USA.

Artiawati, University of Surabaya, Indonesia.

Anne Bardoel, Monash University, Australia.

Anat Drach-Zahavy, University of Haifa, Israel.

Leslie B. Hammer, Portland State University, USA.

Ting-Pang Huang, Soochow University, Taiwan.

Donna S. Lero, University of Guelph, Canada.

Tripti Pande-Desai, New Delhi Institute of Management, India.

Steven Poelmans, EADA Business School, Spain.

Ujvala Rajadhyaksha, Governors State University, USA.

Anit Somech, University of Haifa, Israel.

Li Zhang, Harbin Institute of Technology, China. 


\section{Editor(s)}

\section{Biography}

Karen Korabik is Professor Emeritus of Psychology at the University of Guelph, Canada where she is affiliated with the Centre for Families, Work, and WellBeing. Her research centers on leadership, gender dynamics in organizations, and work-family integration.

Zeynep Aycan is Professor of Psychology and Management at Koç University, Turkey. She received her Ph.D. from Queen's University, Canada and conducted post-doctoral studies at McGill University. Her research focuses on the impact of culture on leadership, human resource management, and work-life balance. She is a Fellow of SIOP and APS.

Roya Ayman is Professor of Psychology and Industrial and Organizational Psychology Program Director at Illinois Institute of Technology, USA. She received her Ph.D. from the University of Utah. Her research focuses on leadership effectiveness in diverse and global workplace, and social support in the work-family interface. She is a Fellow of the Leadership Trust, UK. 


\section{Table of Contents}

Part I. Examining the Impact of Culture on the Work-Family Interface 1. Introducing Project 3535: Lessons Learned from a Multicultural Collaborative Research Project on the Work-Family Interface Zeynep Aycan

2. Methodology, Measurement, and Country Classification Karen Korabik

3. The Impact of National Context and Organizational Policies: A Cross-Cultural Analysis Donna S. Lero and Anne Bardoel

Part II: The Work-Family Interface in Different Countries in the World

4. The Work-Family Interface in the United States Roya Ayman, Leslie Hammer, and Nahren Ishaya

5. The Work-Family Interface in Canada Donna S. Lero and Karen Korabik

6. The Work-Family Interface in Australia Anne Bardoel

7. The Work-Family Interface in Israel Anat Drach-Zahavy and Anit Somech

8. The Work-Family Interface in Turkey Ayşe Burçin Erarslan-Baskurt and Zeynep Aycan

9. The Work-Family Interface in India Tripti Pande-Desai and Ujvala Rajadhyaksha

10. The Work-Family Interface in Indonesia Artiawati

11. The Work-Family Interface in the People's Republic of China Zhang Li and Karen Korabik

12. The Work-Family Interface in Taiwan Ting-Pang Huang

\section{Part III: Work-Family Issues in Global Context}

13. An Integrative Model of Work-Family Conflict: Pancultural Effects and CrossCultural Differences Zeynep Aycan and Karen Korabik

14. Positive Spillover of the Work and Life Domains Barbara Beham, Anne Bardoel, and Steven Poelmans

15. Understanding the Role of Personal Coping Strategy in Decreasing Work and Family Conflict: A Cross-Cultural Perspective Anit Somech and Anat DrachZahavy 
16. Social Support and the Work-Family Interface from a Cross-Cultural Perspective Roya Ayman

17. The Role of Work-Family Guilt in the Work-Family Interface: A Cross-Cultural Analysis Karen Korabik

18. Work-Family Conflict and Positive Spillover: Examining the Interaction of Gender, Gender-Role Ideology, and National Gender Equity Culture Ujvala Rajadhyaksha

19. Exploring the Interaction of Culture and Contextual Factors on the WorkFamily Interface Ujvala Rajadhyaksha

20. Conclusion: Contributions of Project 3535 to Theory, Research, and Practice Karen Korabik 